\title{
Isolation and Screening of Chlorella Sorokiniana for Wastewater Treatment and Biodiesel Production
}

\author{
Manjunatha S.S ${ }^{1}$ and S.T. Girisha ${ }^{2^{*}}$ \\ ${ }^{1,2 *}$ Department of Microbiology and Biotechnology, Jnanabharathi Campus, Bangalore University, Bangalore, India. \\ *Corresponding author: second author_stgirisha@gmail.com Tel: +91 9448439030
}

Available online at: www.isroset.org

Received: 20/Mar/2019, Accepted: 11/Apr/2019, Online: 30/Apr/2019

\begin{abstract}
Microalgae grown on wastewater are a probable source of low cost wastewater treatment and biodiesel production. In the study, microalgae was enumerated and identified as Chlorella sorokiniana by $18 \mathrm{~S}$ rDNA sequence which was cultivated in different wastewater for nutrient removal as well as biodiesel production were studied. The results reveal that the $\mathrm{pH}$ of different wastewater samples almost neutralized by microalgae, the total dissolved solids elimination ranging from 52 to $66 \%$, the biological oxygen demand removal efficiency varied much among different wastewaters the removal rate is of 72 to $90 \%$, the chemical oxygen demand removal ranges from 59 to $75 \%$. The magnesium level was decreased and efficiency is about 36 to $60 \%$, the sulphates absorption efficiency was ranging from 57 to $68 \%$ and the chloride removal efficiency was 13 to $33 \%$. The lipid content was obtained from the algal biomass which are grown in different wastewater samples was transesterified for biodiesel production, the biodiesel was analyzed by FTIR which meets the ASTM and EU standards, hence from the current study it is evident that Chlorella sorokiniana can be effectively used for potential source for phycoremediation and biodiesel production.
\end{abstract}

Keywords: Chlorella sorokiniana, Wastewater, Biomass, Lipid, Transesterification, Biodiesel

\section{INTRODUCTION}

Sustainable energy production and advanced wastewater treatment are two major challenges faced by current society. Many parts of everyday life depends on fuels, in specific the transportation of goods and people. Main energy resources come from fossil fuels such as petro-oil, coal and natural gas [1]. Fossil fuel contributes $80 \%$ of the world's energy requirements. This condition leads to a strong dependence on fossil fuels everyday life. The growth of the population is not covered by produced domestic crude oil [2], hence, renewable energy sources will be alternative to fossil fuel energy sources which will enable the satisfaction of growing energy demand without the emission of greenhouse gas [3] and have gained increasing attention for current and future utilization [4].

The water demand is growing fast because, the population having more than doubled in the past 30 years to about 280 million, could double again in the next 30 years. As population has grown against a background of controlled freshwater resources, so the water existing to individuals has fallen dramatically [5]. Water courses get pollution from many different sources, life styles and technologies practiced in the producing society reflect the composition of wastewater [6]. It is a multifarious combination of natural, organic and inorganic materials as well as synthetic compounds.

Microalgae present a variety of advantages over terrestrial plants for the production of renewable fuels and chemicals. Chief among these is the fact that many species of algae display high growth rates and they can be grown using wastewater on nonarable land, thus avoiding disagreeable competition with food crops for land and water resources [7], they have the possible to produce more oil per acre than any other feedstock being used to produce biodiesel and they can be grown on land that's unsuitable for food crops [8] The rapid growth rate and high lipid yield make microalgae ideally suited to produce biodiesel [9] Chlorella species mainly targeted because of their high lipid [10].

Algal systems have usually been occupied as a tertiary process [11], they have been proposed as a potential secondary treatment system [12]. Wastewaters are rich in nitrogen, phosphorus, micro nutrients and other organic compounds which cause eutrophication in natural water bodies. Microalgae-based systems for wastewater treatment have received a great compact of interest in recent years due to their varied advantages. Microalgae grows on wastewater and under extreme 
conditions have the maximal percentage of oil content with regard to its biomass, which makes it a commutual source for biofuel production[13]. Microalgae, such as Scenedesmus and Chlorella are commonly used in the treatment of wastewater as their capacities of nutrient removal and lipid accumulation being testified. Due to the ability of microalgae to use inorganic nitrogen and phosphorus for their growth, offer an elegant solution to tertiary and quaternary treatments [6]. These nutrients can be utilized by microalgae, thus providing a cost effective way for bioremediation [14,15] and biomass production. Production of biofuel is a promising way of utilization of the microalgal biomass grown in wastewater [16].

During the past few years biodiesel attracted as a renewable and environmental friendly fuel due to diminishing petroleum reserves and exhaust gases from petroleum diesel, biodiesel has attracted attention during the past few years as a renewable and environmental friendly fuel [17]. Biodiesel is a fatty acid alkyl esters derived from living organisms [18]. For sustainable biodiesel production microalga are largely regarded as an ideal feedstock because, it has a several advantages over other energy crops because of its faster growth rate and higher oil yield [19]. Fourier transform infrared spectrometry (FTIR) is commonly used analytical technique to identify the functional groups present in the biodiesel, based on their energies associated with the molecular vibrations.

In the present study Chlorella sorokiniana was isolated, characterized and cultivation in wastewater for the production of lipid as well as nutrient removal from wastewater. Further, the obtained lipid was transesterified for biodiesel production and characterized by FTIR.

\section{MATERIALS AND METHODS}

\section{Enumeration of microalgae}

The fresh water algae strain isolated from Hebbal Lake of Bengaluru (Karnataka, India). $10 \mathrm{ml}$ of the water sample were inoculated into the $250 \mathrm{~mL}$ flasks containing BG11 media and incubated at room temperature $\left(28 \pm 2^{\circ} \mathrm{C}\right)$ under $16: 8 \mathrm{~h}$ light:dark condition fluorescent white light for 4 weeks for preliminary growth. Repeated streak-plating will be carried out to pick up single colony from earlier streaked plates and to make free from bacteria. From last streaked plates, the single colonies will be picked up by loop and allowed to grow in tubes and vials. Before putting in the tubes and vials, the single cell growth and purity of single species was confirmed after observing under microscope [20] Microalgae were further subjected for molecular based identification using PCR based 18S rDNA sequence analysis [21]. A phylogenetic tree was constructed from the obtained rDNA sequence of the isolated strains.

\section{Study of physical and chemical properties of wastewater samples}

Water samples were collected from sewage treatment plant (STP), effluent treatment plant (ETP), fishery fisheries water and sewage drainage (raw sewage water, sewage 50\% dilution and sewage 25\% dilution) in polyethylene carbonyl bottles of 1 liter capacity. All wastewaters were filtered and autoclaved at $121^{\circ} \mathrm{C}$ for 20 minutes and divided equally and one set was stored at $4^{\circ} \mathrm{C}$ for further analysis [22]. Initially, the water samples were subjected for the analysis of $\mathrm{pH}$, TDS, Biological, Chemical oxygen demand, Magnesium, Sulphates and Chloride by standard testing methods. Later same wastewater samples are once again subjected for physicochemical characterization to know the changes in the wastewater characters after microalgal cultivation.

\section{Determination of algal growth}

The pre cultured microalgae was inoculated at $10 \%$ in $500 \mathrm{ml}$ Erlenmeyer flasks containing different wastewater samples. The BG-11 inoculated with algal culture served as the control. Samples were taken from the cultured flask for every three days (up to 8 weeks) and the optical density was measured at $680 \mathrm{~nm}$ using a colorimeter.

\section{Harvesting of algal biomass}

The algae was harvested by centrifugation at $10000 \mathrm{rpm}$ for 10 minutes and the cells are washed once with distilled water and re-centrifuged. The pellet was dried in hot air oven for 2 hour at $60^{\circ} \mathrm{C}$ and the dry weight of algal biomass was determined.

\section{Lipid extraction}

Total lipid content was calculated with the modified Bligh-Dyer method [23], $100 \mathrm{mg}$ of dried algal cells, $8 \mathrm{ml}$ water, $10 \mathrm{ml}$ chloroform and $20 \mathrm{ml}$ methanol were added to each bottle. After for $10 \mathrm{~min}$ sonication, $10 \mathrm{ml}$ water and $10 \mathrm{ml}$ chloroform were added, and the mixture was sonicated for another $10 \mathrm{~min}$. The lower chloroform layer was collected and evaporated in an oven at $60^{\circ} \mathrm{C}$. 


\section{Transesterification}

Alkaline transesterification using sodium methoxide solution [24].

\section{Fourier transform infra-red spectroscopy (FTIR)}

The characteristic functional groups present in the obtained biodiesel were analyzed using FTIR. The samples were scanned in the range of 500 to $4000 \mathrm{~cm}^{-1}$ to obtain FTIR spectra [25].

\section{Statistical analysis}

Statistical analysis was done by calculating mean, standard deviation and error. The graph was plotted for the mean (average) of each parameters.

\section{RESULTS AND DISCUSSION}

\section{Microscopic and molecular identification of microalgae}

The microscopic view of freshwater MA-5 samples showed characteristic emerald-green color, spherical cell, autospores (Figure 1a) and pleasant grass odor which confirms the observation made by [26], the consistent with characteristics of the genus Chlorella. The BLAST and phylogeny analysis in nucleotide database revealed that the microalgal strain shows the closely relative to Chlorella sorokiniana with maximum similarity of 99\% (Figure 1b) which confirms the results of [27], it was previously studied for treatment of wastewater as well as biodiesel production by [28] which is supported by [29] .

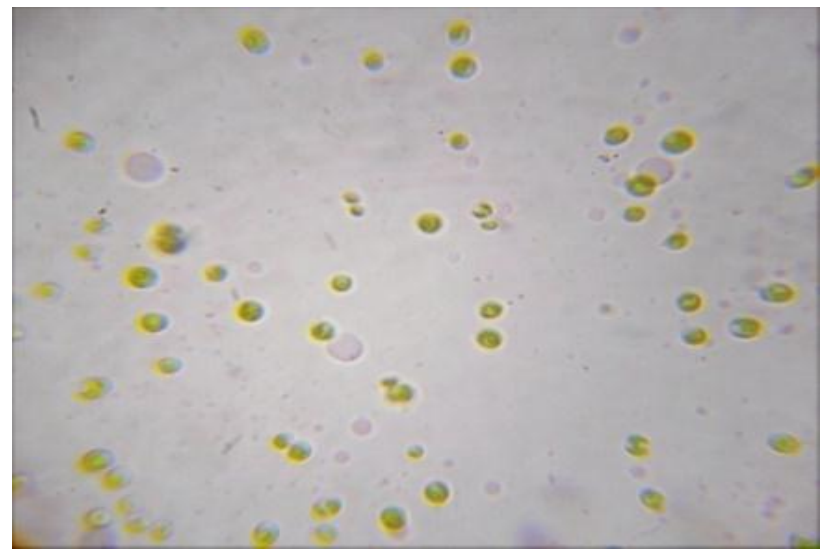

Figure 1a. Microscopic view of Chlorella sorokiniana (100X).

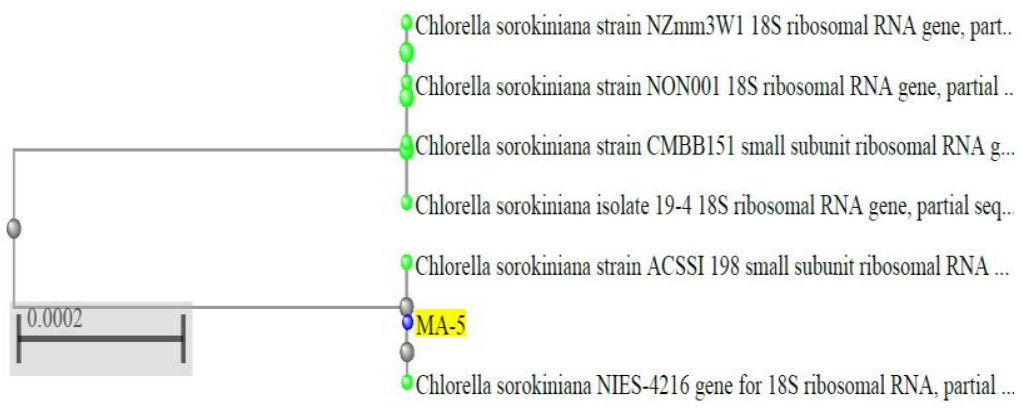

Figure 1b. Phylogenetic analysis of isolated strain.

\section{Physicochemical properties of wastewater samples before and after microalgae cultivation}

The collected wastewater samples of sewage treatment plant (STP), effluent treatment plant (ETP), fishery water, raw sewage water, sewage water $50 \%$ dilution and sewage water $25 \%$ dilution (Figure 2) were analyzed for physic-chemical parameters before algal inoculation and depicted in table 1. The $\mathrm{pH}$ was highest in fisheries water (8.0) and lowest in ETP (6.5), where the TDS was maximum in raw sewage water $\left(620 \mathrm{mgL}^{-1}\right)$ and minimum in sewage water $25 \%$ dilution $\left(168 \mathrm{mgL}^{-1}\right)$. The BOD was 
highest in raw sewage water $\left(452 \mathrm{mgL}^{-1}\right)$ and lowest in fisheries water $\left(63 \mathrm{mgL}^{-1}\right)$ and the COD was maximum in raw sewage water $\left(312 \mathrm{mgL}^{-1}\right)$ and minimum in fisheries water $\left(89 \mathrm{mgL}^{-1}\right)$.

The magnesium content was more in raw sewage water $\left(97 \mathrm{mgL}^{-1}\right)$ whereas less in sewage water $25 \%$ dilution $\left(21 \mathrm{mgL}{ }^{-1}\right)$, were the other nutrient like sulphate was maximum in raw sewage water $\left(60 \mathrm{mgL}^{-1}\right)$ and minimum in fisheries water $(13 \mathrm{mgL}$ $\left.{ }^{1}\right)$, the chlorine level varies among the sample its concentration was more in raw sewage water $\left(1690 \mathrm{mgL}^{-1}\right)$ and less in fisheries water $\left(215 \mathrm{mgL}^{-1}\right)$, which directly indicates that contamination levels of water samples.
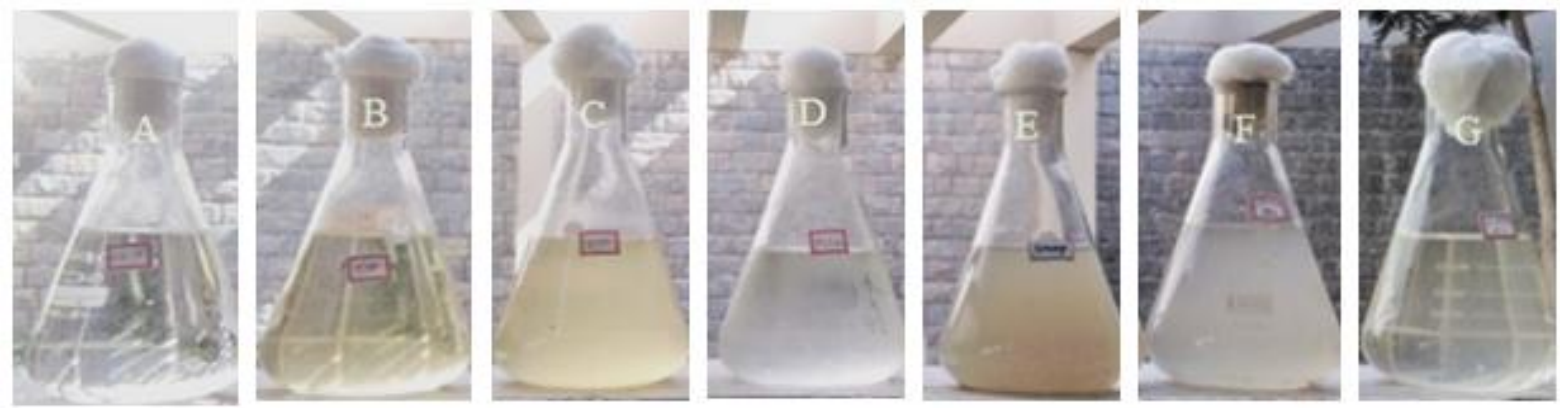

Figure 2. The culture flasks before algal inoculation: A: BG 11 media (Control), B: Sewage treatment plant water (STP), C: Effluent treatment plant water (ETP), D: Fisheries water, E: Raw sewage water, F: Sewage water 50\% dilution, G: Sewage water $25 \%$ dilution.

Table 1. Physicochemical parameters of wastewaters before algal inoculation.

\begin{tabular}{|c|c|c|c|c|c|c|}
\hline Sample & $\begin{array}{c}\text { Sewage } \\
\text { treatment } \\
\text { plant } \\
\text { water } \\
\text { (STP) }\end{array}$ & $\begin{array}{c}\text { Effluent } \\
\text { treatment } \\
\text { plant water } \\
\text { (ETP) }\end{array}$ & Fisheries water & $\begin{array}{l}\text { Raw sewage } \\
\text { water }\end{array}$ & $\begin{array}{c}\text { Sewage } \\
\text { water } 50 \% \\
\text { dilution }\end{array}$ & $\begin{array}{c}\text { Sewage } \\
\text { water } \\
25 \% \\
\text { dilution. }\end{array}$ \\
\hline pH & 7.7 & 6.5 & 8.0 & 6.9 & 7.1 & 7.0 \\
\hline TDS mg/L & 422 & 398 & 310 & 620 & 332 & 168 \\
\hline BOD mg/L & 80 & 120 & 63 & 452 & 250 & 165 \\
\hline COD mg/L & 96 & 257 & 89 & 312 & 236 & 149 \\
\hline Mg mg/L & 61 & 84 & 42 & 97 & 48 & 21 \\
\hline $\mathrm{So}^{4-} \mathrm{mg} / \mathrm{L}$ & 23 & 40 & 13 & 60 & 33 & 19 \\
\hline $\mathrm{Cl}^{-} \mathrm{mg} / \mathrm{L}$ & 518 & 1474 & 215 & 1690 & 846 & 336 \\
\hline
\end{tabular}

After knowing the physicochemical parameters of all water samples, the microalgae was inoculated and subjected for 24 days growth which was depicted in Figure 3. The results indicate the suitability of wastewater for the biomass and production for
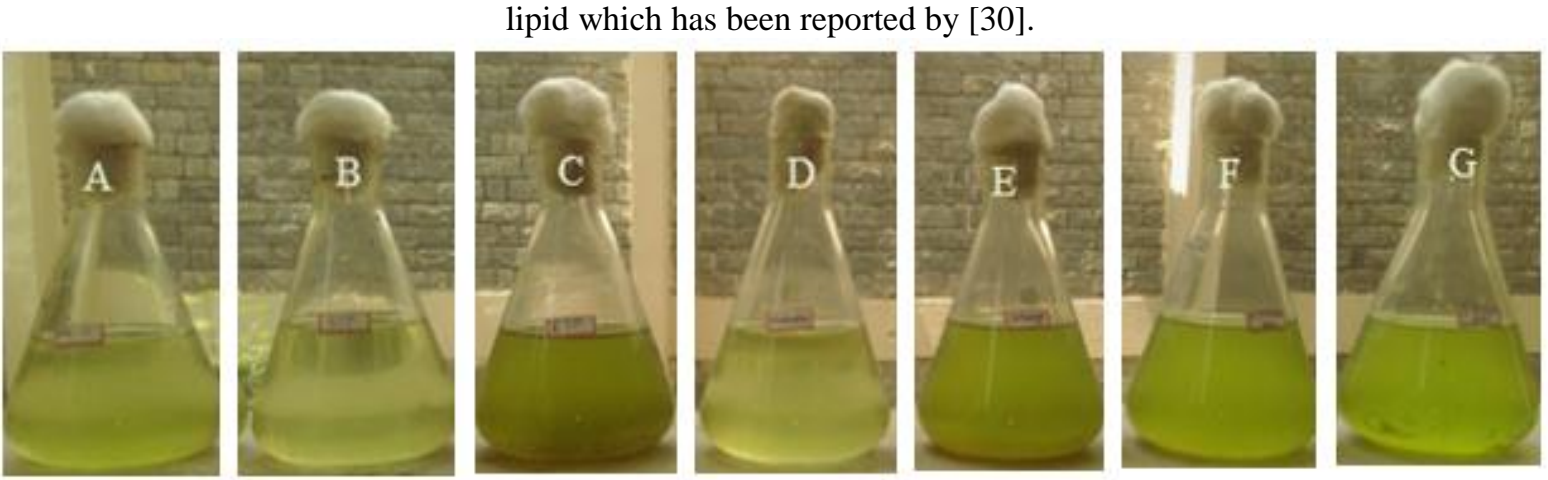

Figure 3. The culture flasks after algal inoculation $\left(24^{\text {th }}\right.$ day $)$

The physicochemical parameters of wastewaters after algal inoculation were depicted in Table 2. Before inoculation of $C$. sorokiniana, the $\mathrm{pH}$ of the water samples are both acidic and basic. After the growth of microalgae it's almost neutralized 
(Table 2). Which justify the report made by [31] in Chlorella sp. cultivated in dairy wastewater. The highest reducing of $\mathrm{pH}$ was observed in fisheries water (0.65) and lowest in STP (0.49), interestingly it was also increased in ETP (0.6), raw sewage water $(0.1)$ and it remain constant in sewage water $50 \%$ dilution and sewage water $25 \%$ dilution this is because of the constant maintenance of $\mathrm{CO}_{2}$ in water samples and absorption of metal ions.

TDS means organic and inorganic particles larger than 2 microns which includes metal ions. TDS removal efficiency varied among different waste water samples, which was ranging from $52 \%$ in sewage $25 \%$ dilution sample to $66 \%$ in raw sewage water, because of algal absorption the TDS was reduced (Table 2). This study confirms the previous reports on reduction in TDS was observed in C. minutissima (97.57\%) by [32]. Due to consumption of dissolved solid from wastewater which was nutrient rich for the growth of microalgae.

Biochemical oxygen demand means the amount of dissolved oxygen used by microorganisms in the biological process of metabolizing organic matter in water. The reduction in BOD value varies among different wastewaters samples, it was $72 \%$ reduced in ETP and 90\% reduced in raw sewage water (Table 2) the results were supported by [33], treatment of domestic wastewater using algae reduced the BOD to $68.4 \%$.

Chemical oxygen demand is a measurement of the oxygen required to oxidize soluble and particulate organic matter in water. This was varied in different waste water samples, the removal rates of 59\% in STP and 75\% in raw sewage water (Table 2). The obtained results comparable with the COD removal with algae on different wastewaters by [34], the obtained results are based on different metabolic pathways, i.e., heterotrophic and autotrophic growth of algae under different culture conditions. The carbon matters in effluents are mostly inert, thus cannot further utilized by algae. [35] Reported that, Chlorella sorokiniana can undergo mixotrophic growth while consuming organic carbon, which has been also reported by [36].

Magnesium level was decreased, the removal efficiency was 36\% in STP and 60\% in ETP water, which is very much needed in smaller amount for microalgal growth. The Mg was observed by algae, which verifies the report made by [37]. The changes in the magnesium concentration after the algal growth are shown in Table 2. Sulphates removal efficiency was ranging from 57\% in S 25 sample to $68 \%$ of raw sewage water (Table 2) which is also important for microalgal growth, where the results are proved by [38]. Chloride removal efficiency was differ in all the samples, which was $13 \%$ in sewage water $25 \%$ dilution and lowest in raw sewage water (33\%) (Table 2), which confirms the similar results of [39].

Table 2. Physicochemical parameters of wastewaters after Chlorella sorokiniana cultivation.

\begin{tabular}{|l|c|c|c|c|c|c|}
\hline Sample & $\begin{array}{c}\text { Sewage } \\
\text { treatment } \\
\text { plant } \\
\text { water } \\
\text { (STP) }\end{array}$ & $\begin{array}{c}\text { Effluent } \\
\text { treatment } \\
\text { plant water } \\
\text { (ETP) }\end{array}$ & Fisheries water & $\begin{array}{c}\text { Raw sewage } \\
\text { water }\end{array}$ & $\begin{array}{c}\text { Sewage } \\
\text { water 50\% } \\
\text { dilution }\end{array}$ & $\begin{array}{c}\text { Sewage } \\
\text { water } \\
\mathbf{2 5 \%} \\
\text { dilution. }\end{array}$ \\
\hline pH & 7.7 & $\mathbf{6 . 5}$ & $\mathbf{8 . 0}$ & 6.9 & 7.1 & 7.0 \\
\hline TDS mg/L & 422 & 398 & 310 & $\mathbf{6 2 0}$ & 332 & $\mathbf{1 6 8}$ \\
\hline BOD mg/L & 80 & 120 & $\mathbf{6 3}$ & $\mathbf{4 5 2}$ & 250 & 165 \\
\hline $\mathbf{C O D ~ m g / L ~}$ & 96 & 257 & $\mathbf{8 9}$ & $\mathbf{3 1 2}$ & 236 & 149 \\
\hline $\mathbf{M g} \mathbf{~ m g / L}$ & 61 & 84 & 42 & $\mathbf{9 7}$ & 48 & $\mathbf{2 1}$ \\
\hline $\mathbf{S o}^{-\mathbf{m g}} \mathbf{~} / \mathbf{L}$ & 23 & 40 & $\mathbf{1 3}$ & $\mathbf{6 0}$ & 33 & 19 \\
\hline $\mathbf{C l}^{-} \mathbf{~ m g / L ~}$ & 518 & 1474 & $\mathbf{2 1 5}$ & $\mathbf{1 6 9 0}$ & 846 & 336 \\
\hline
\end{tabular}

\section{Growth curve of Chlorella sorokiniana}

In algal growth curve no log phases were observed in all the five curves except ETP and raw sewage, which indicates that the isolated wild algae well adopted in all the six wastewater samples, where exponential growth phase in next twenty-one days were present in all wastewater samples. Moreover, it can be found that the algal growth was significantly enhanced in raw sewage, sewage water 50\% dilution and sewage water $25 \%$ dilution because of its much higher levels of calcium, nitrogen, phosphorus and COD than the other three wastewater samples. Therefore, the results shows that sewage water diluted to sewage water $25 \%$ dilution is suitable for algal growth despite its highly unbalanced N/P ratio (Figure 4). Algal cells grew better in wastewater after primary settling than in the effluent because of the higher nutrients concentration, which was also evidenced by [12]. 


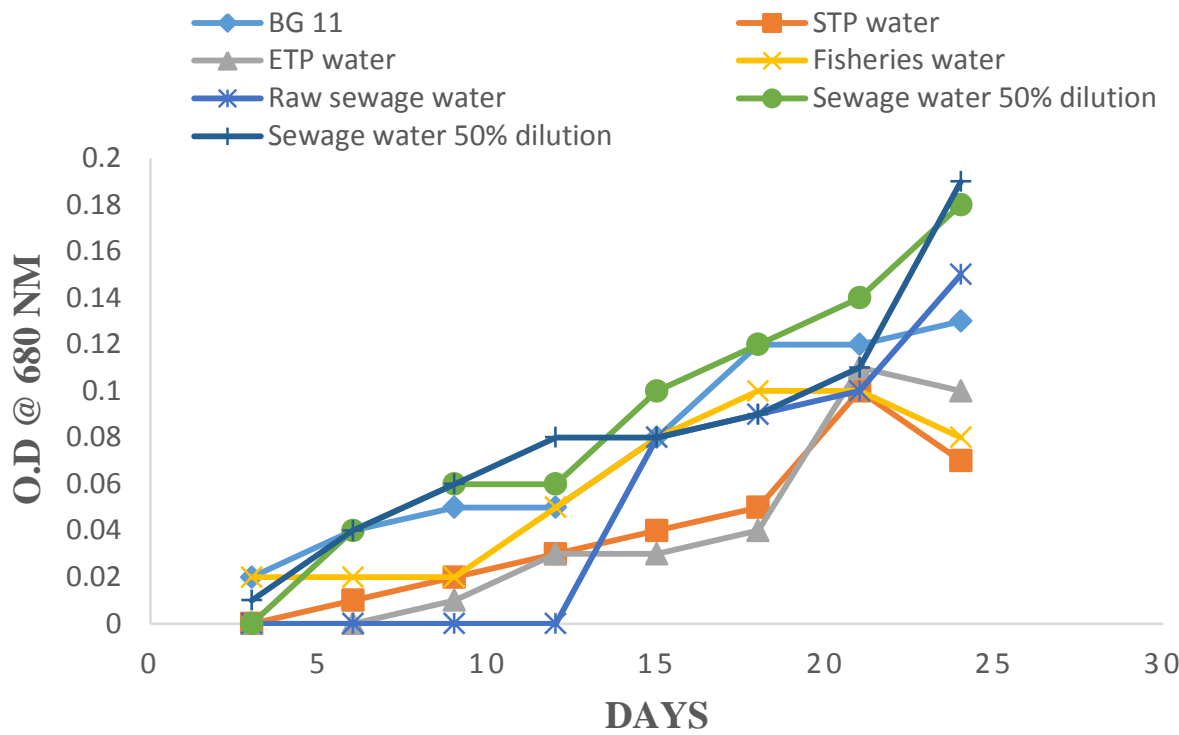

Figure 4. Growth curve of microalgae.

\section{Biomass of Chlorella sorokiniana}

The harvested algal biomass was shown in figure 5.

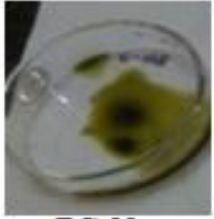

BG-11

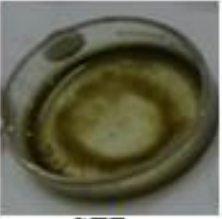

STP

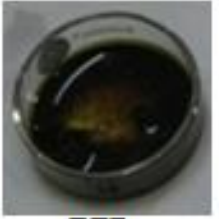

ETP

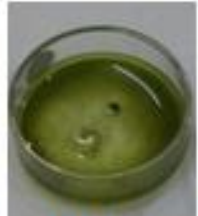

Fisheries

water

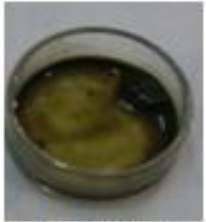

Raw sewage

water

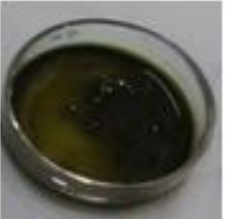

Sewage water

$\mathbf{5 0} \%$ dilution

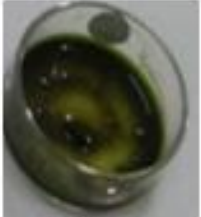

Sewage

water $\mathbf{5 0 \%}$

dilution

Figure 5. Harvested algal biomass.

The algal biomass was dried and the weight was determined by gravimetric method, expressed in terms of $\mathrm{gL}^{-1}$, the biomass obtained is highest in BG 11 media $\left(1.50 \pm 0.4 \mathrm{gL}^{-1}\right)$, followed by $1.13 \pm 0.2 \mathrm{gL}^{-1}$ in fisheries wastewater and the lowest biomass obtained in raw sewage water $0.95 \pm 0.3 \mathrm{gL}^{-1}$ (Table 3), the results are higher compared with the biomass productivity of Chlorella sp. was studied by [40] obtained the biomass of was $0.681 \mathrm{~g} \mathrm{~L}^{-1}$. The mixotrophic growth with wastewater was previously suggested by [41] and supported by [42].

Table 3. Dry weight of algal biomass.

\begin{tabular}{|l|c|}
\hline Sample & Weight of dry biomass $\mathbf{~ g L}^{-1}$ ) \\
\hline BG 11 & $1.50 \pm 0.4$ \\
\hline Sewage treatment plant water (STP) & $0.97 \pm 0.1$ \\
\hline Effluent treatment plant water (ETP) & $0.80 \pm 0.2$ \\
\hline Fisheries water & $1.13 \pm 0.2$ \\
\hline Raw sewage water & $0.95 \pm 0.3$ \\
\hline Sewage water 50\% dilution & $0.99 \pm 0.5$ \\
\hline Sewage water 50\% dilution & $1.10 \pm 0.6$ \\
\hline
\end{tabular}




\section{Extracted lipid and transesterification}

The extract lipid was shown in Figure 6a, the result obtained herein supports with a related study by [43]. Alkaline transesterified of algal lipid which yielded two different layers of product, the upper layer shows biodiesel and the lower layer shows bio glycerol (Figure 6b), where alkali based method is most widely used as it has high efficiency of biodiesel yield $(84.52 \%)$ as reported by [44].

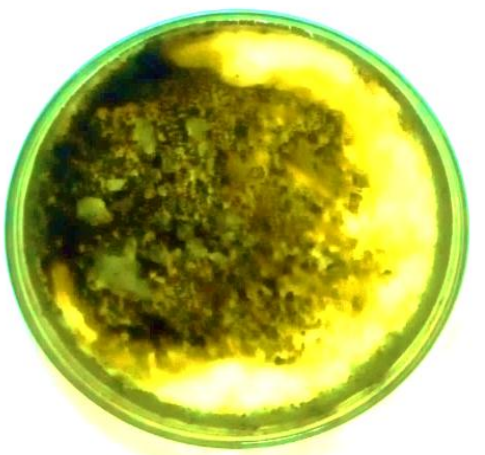

Figure 6a. Extracted lipid.

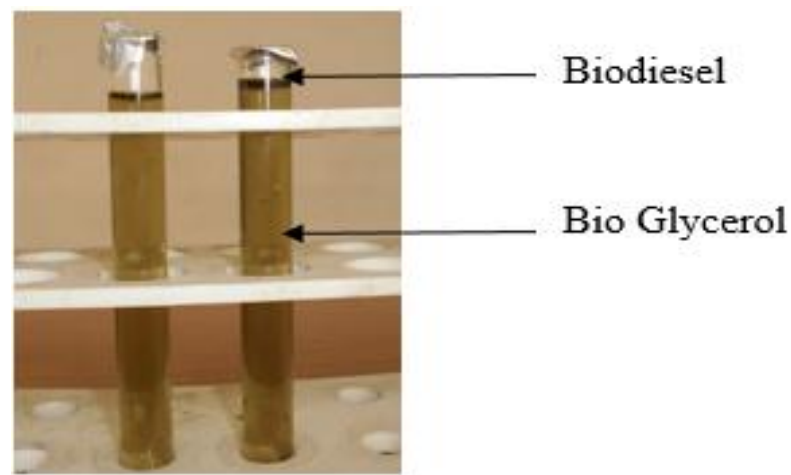

Figure 6b. Test tubes showing Biodiesel and Bio glycerol.

\section{FTIR peak of Biodiesel}

By comparing the FTIR peak (Figure 7) with standard chemical bond with respect wave length the following results were found.

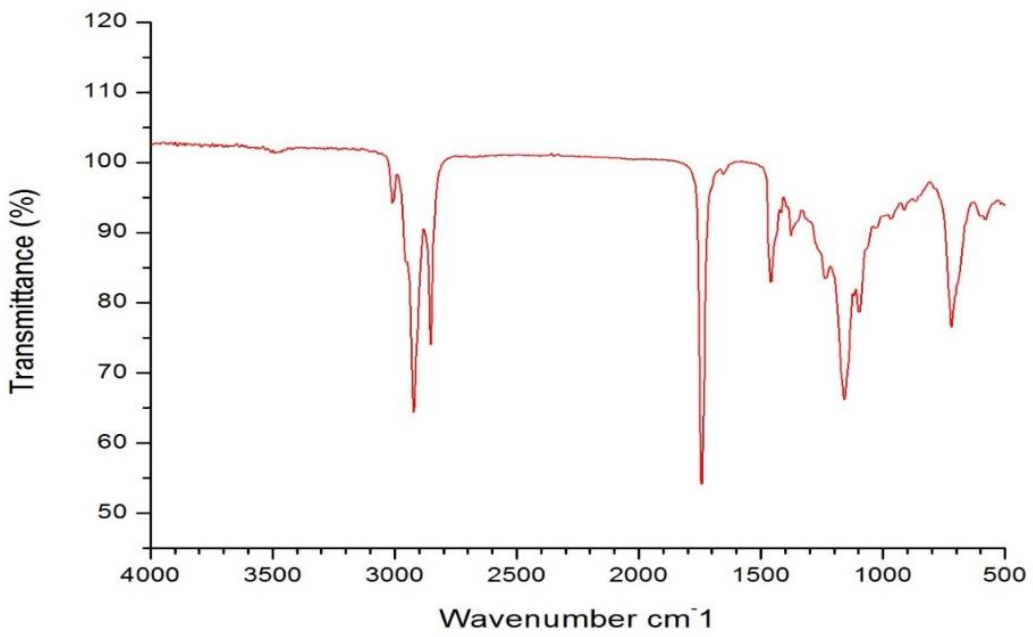

Figure 7. FTIR of Biodiesel.

The most characteristic peaks on a biodiesel spectrum is one at $1000-1300 \mathrm{~cm}^{-1}$ which is related to $\mathrm{O}-\mathrm{CH}_{3}$ vibrations. The shows that peak characterized by $\mathrm{O}-\mathrm{CH}_{3}$ vibrations is prominent in all the spectra. The peak gives the indication of the attachment of the alkali group of the alcohol to the fatty acid group. In addition there are bands appearing between 1150-1450 $\mathrm{cm}^{-1}$ attributed to $\mathrm{C}-\mathrm{O}$ ester stretching vibrations and $1735-1750 \mathrm{~cm}^{-1}$ both attributed to $\mathrm{C}=\mathrm{O}$ ester stretching vibrations, 1000$1400 \mathrm{~cm}^{-1}$ attributed to alkyl halide C-F stretching vibrations, $1080-1360 \mathrm{~cm}^{-1}$ attributed to amine group C-N stretching vibrations, $2850-3000 \mathrm{~cm}^{-1}$ attributed to alkanes $\mathrm{C}-\mathrm{H}$ stretching vibrations, $1720-1740 \mathrm{~cm}^{-1}$ attributed to aldehyde group C=O stretching vibrations, $1670-1820 \mathrm{~cm}^{-1}$ attributed to ester carbonyl $\mathrm{C}=\mathrm{O}$ stretching vibrations, $2500-3300 \mathrm{~cm}^{-1}$ attributed to acid group $\mathrm{O}-\mathrm{H}$ stretching vibrations and $1400-1600 \mathrm{~cm}^{-1}$ attributed to aromatic groups $\mathrm{C}=\mathrm{C}$ stretching vibrations. Which corroborates the report made by [45] of biodiesel produced from Spirulina and Chlorella. The analysis confirms the purity of the respective biodiesel samples with the presence of methyl ester groups. It could be concluded that the fatty acid methyl esters are confirming with ASTM and EU standards of biodiesel.

\section{CONCLUSIONS}


Microalgae is an alternative source for the production of biodiesel for commercial purposes and it can also use for the wastewater treatment. Our study mainly focused on isolation of microalgae from lake water samples, cultivation in different wastewater samples and production of biodiesel by lipid transesterification. Chlorella sorokiniana grown luxuriantly in all the kinds of wastewater selected for the study. Effective pollutants removal was achieved. Conclusively, Chlorella sorokiniana can be used for wastewater treatment can serve low-cost cultivation system for producing higher biomass of microalgae and that biomass can be used for the production of biodiesel in the near future.

\section{ACKNOWLEDGEMENTS}

The author is thank full to Department of Backward classes welfare, Karnataka for funding this work and Bangalore University for SAP laboratory facilities.

\section{REFERENCES}

[1] B.M. Gitte, S. Siraj, H.M. Dharmadhikari, "Performance and Emission Characteristics of Diesel Engine Fuelled with Biodiesel and its Blend: A review", International Journal of Engineering Research \& Technology, No.2, pp.3235-3243, 2013.

[2] A. Demirbas, "Biofuels securing the planet's future energy needs", Energy conversion and management, Vol.50, No.9, pp.2239-2249, 2009.

[3] J. Yaghoubi, M. Yazdanpanah, N. Komendantova, "Iranian agriculture advisors' perception and intention toward biofuel: Green way toward energy security, rural development and climate change mitigation", Renewable Energy, Vol.130, pp.452-459, 2019.

[4] D. Huang, H. Zhou, L. Lin, "Biodiesel: an alternative to conventional fuel”, Energy Procedia, Vol.16, pp.1874-1885, 2012.

[5] N. Abdel-Raouf, A.A. Al-Homaidan, I.B.M. Ibraheem, "Microalgae and wastewater treatment", Saudi journal of biological sciences, Vol.19, No.3, pp.257-275, 2012.

[6] N.F. Gray, "Biology of Wastewater Treatment", Oxford Univ. Press, Oxford, 1989.

[7] C. Zhao, T. Brück, J.A. Lercher, "Catalytic deoxygenation of microalgae oil to green hydrocarbons", Green Chemistry, Vol.15, No.7, pp.17201739, 2013.

[8] I. Ozkurt, "Qualifying of safflower and algae for energy", Energy Educ Sci Technol, Vol.23 (part A), No.1, pp.145-151, 2009.

[9] Y. Chisti, "Biodiesel from microalgae", Biotechnology advances, Vol.25, No.3, pp.294-306, 2007.

[10] Y. Liang, N. Sarkany, Y. Cui, "Biomass and lipid productivities of Chlorella vulgaris under autotrophic, heterotrophic and mixotrophic growth conditions", Biotechnology letters, Vol.31, No.7, pp.1043-1049, 2009.

[11] W.J. Oswald, "Micro-algae and wastewater treatment", Microalgal biotechnology, pp.305-328, 1988.

[12] N.F.Y. Tam, Y.S. Wong, "Wastewater nutrient removal by Chlorella pyrenoidosa and Scenedesmus sp”, Environmental Pollution, Vol.58, No.1, pp.19-34, 1989.

[13] U.F. Meeranayak, C.T. Shivasharana "Competitive and Economically Feasible Cell Wall Disruption Techniques for Algal Biofuel Extraction", International Journal of Scientific Research in Biological Sciences Vol.5, No.6, pp.121-126, 2018.

[14] W. Zhou, B. Hu, Y. Li, M. Min, M. Mohr, Z. Du, R. Ruan, "Mass cultivation of microalgae on animal wastewater: a sequential two-stage cultivation process for energy crop and omega-3-rich animal feed production", Applied biochemistry and biotechnology, Vol.168, No.2, pp.348-363, 2012.

[15] A.N. Shilton, D.D. Mara, R. Craggs, N. Powell, "Solar-powered aeration and disinfection, anaerobic co-digestion, biological CO2 scrubbing and biofuel production: the energy and carbon management opportunities of waste stabilisation ponds", Water science and technology, Vol.58, No.1, pp.253-258, 2008.

[16] Q. Hu, M. Sommerfeld, E. Jarvis, M. Ghirardi, M. Posewitz, M. Seibert, A. Darzins, "Microalgal triacylglycerols as feedstocks for biofuel production: perspectives and advances", The plant journal, Vol.54, No.4, pp.621-639, 2008.

[17] P.T. Vasudevan, M. Briggs, "Biodiesel production-current state of the art and challenges", Journal of industrial microbiology \& biotechnology, Vol.35, No.5, pp.421, 2008.

[18] J. Janaun, N. Ellis, "Perspectives on biodiesel as a sustainable fuel”, Renewable and Sustainable Energy Reviews, Vol.14, No.4, pp.1312-1320, 2010.

[19] A.B. Fadhil, E.T. Al-Tikrity, M.A. Albadree, "Biodiesel production from mixed non-edible oils, castor seed oil and waste fish oil”, Fuel, Vol.210, pp.721-728, 2017.

[20] S.M. Phang, W.L. Chu, "Algae culture Collection, Catalogue of Strains", Institute of Post Graduate Studies and Research, University of Malaya, Kuala Lumpur, Malaysia, pp.77, 1999.

[21] L.E. Eland, R. Davenport, C.R. Mota, "Evaluation of DNA extraction methods for freshwater eukaryotic microalgae”, Water research, Vol.46, No.16, pp.5355-5364, 2012.

[22] American Public Health Association, "Standard methods for the examination of water and wastewater", 1998.

[23] H.Q. Luyen, J.Y. Cho, H.W. Shin, N.G. Park, Y.K. Hong, "Microalgal growth enhancement by levoglucosan isolated from the green seaweed Monostroma nitidum", Journal of applied phycology, Vol.19, No.2, pp.175-180, 2007.

[24] S.B. Velasquez-Orta, J.G.M. Lee, A. Harvey, "Alkaline in situ transesterification of Chlorella vulgaris", Fuel, Vol.94, pp.544-550, 2012.

[25] A.Y. Oyerinde, E.I. Bello, "Use of fourier transformation infrared (FTIR) spectroscopy for analysis of functional groups in peanut oil biodiesel and its blends", British Journal of Applied Science \& Technology, Vol.13, No.3, pp.1-14, 2016.

[26] H. Qiao, G. Wang, X. Zhang, "Isolation and characterization of Chlorella Sorokiniana GXNN01 (chlorophyta) with the properties of heterotrophic and microaerobic growth", Journal of phycology, Vol.45, No.5, pp.1153-1162, 2009.

[27] V.A. Huss, C. Frank, E.C. Hartmann, M. Hirmer, A. Kloboucek, B.M. Seidel, E. Kessler, "Biochemical taxonomy and molecular phylogeny of the genus Chlorella sensu lato (Chlorophyta)", Journal of Phycology, Vol.35, No.3, pp.587-598, 1999.

[28] S.K. Gupta, F.A. Ansari, A. Shriwastav, N.K. Sahoo, I. Rawat, F. Bux, "Dual role of Chlorella sorokiniana and Scenedesmus obliquus for comprehensive wastewater treatment and biomass production for bio-fuels", Journal of cleaner production, Vol.115, pp.255-264, 2016. 
[29] J.K. Pittman, A.P. Dean, O. Osundeko, "The potential of sustainable algal biofuel production using wastewater resources", Bioresource technology, Vol.102, No.1, pp.17-25, 2011.

[30] Gupta, L. Prabuddha, Hee-Jeong Choi, R. Radheshyam Pawar, P. Sokhee Jung, Seung-Mok Lee. "Enhanced biomass production through optimization of carbon source and utilization of wastewater as a nutrient source", Journal of environmental management, Vol.184, pp.585-595, 2016.

[31] S. Huo, Z. Wang, S. Zhu, W. Zhou, R. Dong, Z. Yuan, “Cultivation of Chlorella zofingiensis in bench-scale outdoor ponds by regulation of pH using dairy wastewater in winter, South China" Bioresource technology, Vol.121, pp.76-82, 2012.

[32] G.K. Sharma, S.A. Khan, "Bioremediation of sewage wastewater using selective algae for manure production", International Journal of Environmental Engineering and Management, Vol.4, No.6, pp.573-580, 2013.

[33] O. Colak, Z. Kaya, "A study on the possibilities of biological wastewater treatment using algae”, Doga Biyolji Serisi, Vol.12, No.1, pp.18-29, 1988.

[34] L. Wang, M. Min, Y. Li, P. Chen, Y. Chen, Y. Liu, R. Ruan, “Cultivation of green algae Chlorella sp. in different wastewaters from municipal wastewater treatment plant", Applied biochemistry and biotechnology, Vol.162, No.4, pp.1174-1186, 2010.

[35] S. Kim, J.E. Park, Y.B. Cho, S.J. Hwang, "Growth rate, organic carbon and nutrient removal rates of Chlorella sorokiniana in autotrophic, heterotrophic and mixotrophic conditions", Bioresource technology, Vol.144, pp.8-13, 2013.

[36] S. Mandal, N. Mallick, "Microalga Scenedesmus obliquus as a potential source for biodiesel production", Applied microbiology and biotechnology, Vol.84, No.2, pp.281-291, 2009.

[37] N.M. Deleebeeck, F. De Laender, V.A. Chepurnov, W. Vyverman, C.R. Janssen, K.A. De Schamphelaere, "A single bioavailability model can accurately predict Ni toxicity to green microalgae in soft and hard surface waters", Water research, Vol.43, No.7, pp.1935-1947, 2009.

[38] W.J. Oswald, "Waste treatment by pond systems, engineering aspects" In Proc. IAWPRC Conference on Appropriate Waste Management Technologies, Perth, Australia, 1991.

[39] N. Renuka, A. Sood, S.K. Ratha, R. Prasanna, A.S. Ahluwalia, "Nutrient sequestration, biomass production by microalgae and phytoremediation of sewage water", International journal of phytoremediation, Vol.15, No.8, pp.789-800, 2013.

[40] C.M. Kuo, T.Y. Chen, T.H. Lin, C.Y. Kao, J.T. Lai, J.S. Chang, C.S. Lin, "Cultivation of Chlorella sp. GD using piggery wastewater for biomass and lipid production", Bioresource technology, Vol.194, pp.326-333, 2015.

[41] X. Li, H. Xu, Q. Wu, "Large-scale biodiesel production from microalga Chlorella protothecoides through heterotrophic cultivation in bioreactors", Biotechnology and bioengineering, Vol.98, No.4, pp.764-771, 2007.

[42] H. Wang, H. Xiong, Z. Hui, X. Zeng, "Mixotrophic cultivation of Chlorella pyrenoidosa with diluted primary piggery wastewater to produce lipids”, Bioresource Technology, Vol.104, pp.215-220, 2012.

[43] A. Ranjan, C. Patil, V.S. Moholkar, "Mechanistic assessment of microalgal lipid extraction", Industrial \& Engineering Chemistry Research, Vol.49, No.6, pp.2979-2985. 2010.

[44] T.C. Loong, A. Idris, "Rapid alkali catalyzed transesterification of microalgae lipids to biodiesel using simultaneous cooling and microwave heating and its optimization", Bioresource technology, Vol.174, pp.311-315, 2014.

[45] P. Nautiyal, K.A. Subramanian, M.G. Dastidar, "Production and characterization of biodiesel from algae", Fuel Processing Technology, Vol.120, pp.79-88, 2014.

\section{Author's Profile}

Manjunatha S.S., Research scholar, Department of Microbiology and Biotechnology, Jnana Bharathi campus, Bangalore University, Bengaluru, India. He has completed M.Sc. Biotechnology from same department. He is having research experience of 3 years and published 2 research papers in reputed journals.

Dr. S.T. Girisha is currently working as Assistant Professor (Stage III), Department of Microbiology and Biotechnology, Jnana Bharathi campus, Bangalore University, Bengaluru, India. His research area is on Biofuel. The author is having 12 years of teaching experience. He has awarded FISBT Award (2007), Mahanshree Nathan Award (2008) and Seva Sikshakaru award (2013). The author has guided for 5 (awarded) +3 (pursuing) Ph.D. students and he has published more than 55 research papers in reputed journals.

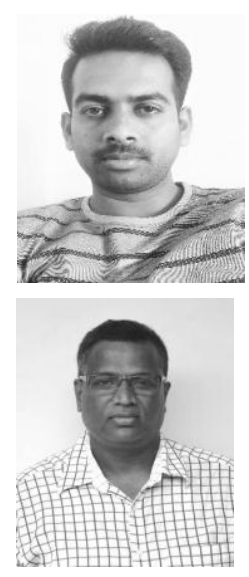

